\title{
Analisis Penggunaan Obat Rasional Dalam Peresepan Pada Kasus ISPA Non Pneumonia Di Rumah Sakit Umum Dr. Pirngadi Kota Medan
}

\author{
Hendrico H.P Simarmata*, Sudiro, Asriwati \\ S2 IImu Kesehatan Masyarakat, Institut Kesehatan Helvetia Medan \\ *Email : hendrico.simarmata@gmail.com
}

\begin{abstract}
ABSTRAK
RSUD DR Pirngadi Medan memiliki jumlah kasus ISPA non Pneumonia cukup banyak di kota Medan dan ditemukan beberapa ketidakrasional peresepan obat oleh dokter. Penelitian ini bertujuan untuk menganalisis obat oleh dokter dalam peresepan penggunaan obat rasional pada kasus ISPA Non Pneumonia. Penelitian ini berjenis kuantitatif. Penelitian berlangsung mulai Juli-Agustus tahun 2020. Populasi penelitian adalah seluruh dokter umum, dokter spesialis paru, dokter spesialis anak dan dokter spesialis penyakit dalam berjumlah 79 orang. Data hasil survey dianalisis dengan menggunakan uji Chi-Square dan regresi linier. Berdasarkan hasil penelitian diketahui bahwa ada hubungan peresepan obat oleh dokter berdasarkan tepat diagnosis $(p=0,000)$, ada hubungan peresepan obat oleh dokter berdasarkan tepat indikasi $(p=0,000)$, ada hubungan peresepan obat oleh dokter berdasarkan tepat jenis obat $(p=0,000)$, ada hubungan peresepan obat oleh dokter berdasarkan tepat dosis $(p=0,000)$, ada hubungan peresepan obat oleh dokter berdasarkan tepat penilaian kondisi pasien $(p=0,000)$, ada hubungan peresepan obat oleh dokter berdasarkan tepat informasi $(p=0,000)$, ada hubungan peresepan obat oleh dokter berdasarkan tepat tindak lanjut dengan penggunaan obat rasional $(p=0,000)$. Kesimpulan dalam penelitian ini yaitu semua variabel dalam penelitian ini berhubungan dengan penggunaan obat rasional pada kasus ISPA Non Pneumonia dan variabel yang paling dominan adalah variabel tepat informasi. Saran penelitian agar dilakukan penyempurnaan pada catatan pasien sehingga profil pasien lebih mudah dilihat dan pengambilan keputusan terapi lebih mudah dan tepat
\end{abstract}

\section{Kata Kunci : Peresepan, Obat Rasional, ISPA non Pneumonia}

\begin{abstract}
RSUD DR Pirngadi Medan has a large number of cases of non-pneumonia ARI in Medan city and found some irrational drug prescriptions by doctors. This study aims to analyze drugs by doctors in prescribing rational drug use in cases of ARI Non Pneumonia. This research is quantitative. The study took place from July-August 2020. The research population consisted of all general practitioners, pulmonary specialists, pediatricians and internal medicine specialists totaling 79 people. The survey data were analyzed using the Chi-Square test and linear regression. Based on the results of the study, it was found that there was a relationship between prescribing drugs by doctors based on correct diagnosis $(p=0.000)$, there was a relationship between prescribing drugs by doctors based on appropriate indications $(p=0.000)$, there was a relationship between prescribing drugs by doctors based on the exact type of drug $(p=0.000)$, there is a relationship between prescribing drugs by doctors based on the right dose $(p=0.000)$, there is a relationship between prescribing drugs by doctors based on the correct assessment of the patient's condition $(p=0.000)$, there is a relationship between prescribing drugs by doctors based on accurate information $(p=0.000)$, there is a relationship prescribing drugs by doctors based on appropriate follow-up with rational drug use $(p=0.000)$. The conclusion in this study is that all variables in this study are related to rational drug use in cases of ARI Non Pneumonia and the most dominant variable is the correct information variable. Research suggestions are to make improvements to patient records so that patient profiles are easier to see and therapeutic decisions are easier and more accurate
\end{abstract}

\section{Keywords : Prescribing, Rational Drugs, Upper Respiratory Tract Infection Case}

\section{PENDAHULUAN}

Obat merupakan salah satu faktor penting dalam pelayanan kesehatan. Penggunaan obat yang tidak tepat, tidak efektif, tidak aman, dan juga tidak ekonomis saat ini telah menjadi masalah dalam pelayanan kesehatan. ${ }^{1}$
Mengacu kepada Sistem Kesehatan Nasional (SKN) Tahun $2009^{2}$ dan Keputusan Menteri Kesehatan Republik Indonesia Nomor 189/ Menkes/SK/III/2012 tentang Kebijakan Obat Nasional (Konas) bahwa, upaya kesehatan adalah bentuk dan cara penyelenggaraan 
upaya kesehatan yang paripurna, terpadu dan berkualitas meliputi upaya peningkatan, pencegahan, pengobatan dan pemulihan yang diselenggarakan guna menjamin tercapainya derajat kesehatan masyarakat yang setinggitingginya. ${ }^{3}$

Berdasarkan data World Health Organization (WHO) tahun 2019 diperkirakan bahwa lebih dari separuh penduduk dunia menggunakan obat yang diresepkan, diberikan dan di jual dengan cara yang tidak tepat dan menggunakan obat secara tidak tepat. Salah satu obat yang perlu mendapatkan peresepan yang tepat adalah antibiotik. ${ }^{4}$ Berdasarkan data WHO tahun 2018 menunjukkan angka kematian akibat bakteri resisten di dunia sekitar 700 ribu pertahun. Dengan cepatnya perkembangan dan penyebaran infeksi akibat bakteri resisten, pada tahun 2050 diperkirakan kematian 10.000 .000 per tahun akibat bakteri resisten lebih besar dibanding kematian akibat kanker.

Penggunaan obat yang tidak rasional dapat berakibat pada hal yang tidak diharapkan, yaitu penurunan kualitas terapi yang dapat meningkatkan angka morbiditas dan mortalitas, sumber daya yang tersia-sia yang dapat mengurangi ketersediaan obat dan meningkatkan biaya pengobatan, efek resiko yang tidak di inginkan mencetuskan terjadinya reaksi yang tidak diinginkan serta resistensi bakteri, dan dampak psikososial yang mengakibatkan ketergantungan pasien terhadap obat yang tidak diperlukan. ${ }^{5}$

Penggunaan obat yang tidak rasional sering dijumpai dalam praktek sehari-hari. Peresepan obat tanpa indikasi yang jelas, penentuan dosis, cara dan lama pemberian yang keliru, serta peresepan obat yang mahal merupakan sebagian contoh dari ketidakrasionalan peresepan. Penggunaan suatu obat dikatakan tidak rasional, jika kemungkinan dampak negatif yang diterima oleh pasien lebih besar dibandingkan manfaatnya.

Berdasarkan data Dinas Kesehatan Provinsi Sumatera Utara Tahun 2017, diketahui bahwa persentase penggunaan antibiotik pada kasus ISPA non Pneumonia $(56,0 \%){ }^{6}$ Infeksi Saluran Pernafasan Atas (ISPA) menjadi penyakit yang paling banyak menyerang masyarakat, khususnya masyarakat kota Medan. Berdasarkan data milik Dinas Kesehatan Kota Medan sepanjang tahun 2018 yang diperoleh, angka kesakitan dari penyakit ini bahkan mencapai sebanyak 203,588 kasus, jauh lebih tinggi dari penyakit umum lainnya, seperti diare, alergi, hipertensi dan lainnya. Oleh sebab itu, penting sekali adanya penelitian tentang peresepan obat rasional terhadap kasus ISPA di fasilitas kesehatan.

Pada penelitian ini, peneliti melihat bagaimana peresepan obat oleh dokter dalam penggunaan obat rasional di RSUD Dr. Pirngadi Kota Medan. Adapun alasan peneliti melakukan penelitian di RSUD Dr. Pirngadi Kota Medan, karena rumah sakit tersebut sudah terakreditasi dan penanggung jawab pengelola obatnya merupakan seorang Apoteker, serta banyak ditemukan peresepan untuk kasus ISPA non Pneumonia yang tidak rasional.

Berdasarkan data investigasi peresepan obat di RSUD Dr. Pirngadi Kota Medan tahun 2019 diketahui bahwa pada bulan Mei tahun 2019 ada beberapa dokter yang tidak menuliskan kekuatan sediaan dan aturan pakai pada resep ceftriaxone injeksi (KNC), sehingga hal ini menunjukkan bahwa dokter tersebut belum mengikuti kaidah penulisan resep yang lengkap. Pada bulan Juni tahun 2019, ditemukan kejadian kesalahan pemberian obat, hal ini akibat dari apoteker belum melakukan prosedur telaah resep sesuai SPO.

Selain itu, berdasarkan laporan medication error di instalasi farmasi RSUD Dr. Pirngadi Kota Medan tahun 2019 diketahui bahwa, pada bulan juni 2019 ditemukan beberapa kejadian yaitu, dokter tidak menuliskan identitas pasien, tidak tertulis kekuatan sediaan dan aturan pakai pada resep ceftriaxone injeksi, tidak tertulis kekuatan sediaan pada resep levofloxacin injeksi dan cefadroxil tablet, dokter menuliskan di resep Micardis $80 \mathrm{mg}$, biasanya pasien menggunakan aspilet $80 \mathrm{mg}$, tidak tertulis aturan pakai pada resep cefixim tabelt $100 \mathrm{mg}$, tidak tertulis aturan pakai (signa) pada resep citicholin 500 mg injeksi.

Kemudian berdasarkan data sekunder yang diperoleh dari Dinas Kesehatan Kota Medan tahun 2017 diketahui bahwa pada Rumah sakit tersebut memiliki jumlah kasus ISPA non Pneumonia (batuk pilek) cukup banyak di kota Medan. Adapun angka kejadian ISPA di RSUD Dr. Pirngadi Kota Medan setiap tahunnya meningkat. Pada tahun 2017 jumlah penderita ISPA yang berkunjung di RSUD Dr. Pirngadi Kota Medan ada sebanyak 8.612 kunjungan, pada tahun 2018 meningkat menjadi 10.110 kunjungan, dan pada tahun 2019 meningkat menjadi 12.729 kunjungan.

Meskipun RSUD Dr. Pirngadi Kota Medan tersebut telah terakreditasi, namun masih ditemukan peresepan obat untuk kasus ISPA non pneumonia yang tidak rasional. Dikatakan tidak rasional karena masih ada peresepan yang polifarmasi, penggunaan antibiotik dan 
injeksi yang berlebihan, serta pemilihan obat yang tidak sesuai dengan standar terapi yang ada. Penggunaan obat dikatakan rasional apabila pasien menerima obat yang sesuai dengan kebutuhannya, untuk periode waktu yang adekuat dengan harga yang terjangkau. Akan tetapi masih ada beberapa dokter yang meresepkan obat tidak rasional seperti antibiotik masih digunakan dalam terapi Infeksi Saluran Pernafasan Akut (ISPA) adalah untuk menyembuhkan atau mencegah penyakit infeksi, tetapi pemilihan antibiotik harus disesuaikan dengan jenis penyakitnya. Cara dan lama pemberian juga harus disesuaikan serta memberikan efek samping yang seminimal mungkin.

Hasil survey awal penelitian yang dilakukan pada tanggal 13 September 2019 untuk mengetahui pengaruh peresepan obat rasional untuk kasus ISPA non Pneumonia di RSUD Dr. Pirngadi Kota Medan, dengan mengambil 10 resep yang diambil secara acak, diketahui bahwa penggunaan peresepan antibiotik untuk kasus ISPA di RSUD Dr. Pirngadi Kota Medan masih cukup tinggi yaitu $>60 \%$.

Selain itu peneliti juga menemukan ada beberapa ketidakrasional peresepan obat oleh dokter berhubungan dengan : 1) ketidaktepatan diagnosis pada pasien seperti penyakit demam Typoid didiagnosis menjadi ISPA, 2) ketidaktepatan indikasi, 3) ketidaktepatan jenis obat, penggunaan obat yang diberikan kepada pasien dengan diagnosa ISPA Atas mempunyai persentase tepat obat sebesar $42,86 \%$, ketidaktepatan obat dikarenakan penggunaan antibiotik sefiksim pada pengobatan faringitis/tonsilitis; 4) ketidaktepatan dosis. Ketidaktepatan pada besaran dosis terjadi karena dosis yang diberikan kurang (Underdose) dan juga dosis yang berlebih (Overdose). Sebanyak 42,86\% dari kasus mendapatkan besaran dosis yang kurang dan sebanyak $11,43 \%$ mendapatkan besaran dosis yang berlebih. Hal ini dapat menyebabkan efektivitas terapi yang tidak maksimal dikarenakan dosis yang kurang dan dapat memicu terjadinya resistensi bakteri serta dapat menimbulkan toksisitas atau terjadinya efek samping yang tidak diinginkan dikarenakan pemberian dosis yang berlebih, 5) ketidaktepatan penilaian terhadap kondisi pasien dikarenakan pasien kurang kooperatif dalam menyampaikan keluhan dan dokter kurang menggali informasi yang mendalam tentang riwayat kesehatan pasien, 6) ketidaktepatan informasi terkait resitensi antibiotik serta pencegahan, 7) ketidaktepatan tindak lanjut seperti penatalaksanaan syok anafilaksis, pemberian injeksi adrenalin yang kedua perlu tidak segera dilakukan. Berdasarkan paparan di atas, maka peneliti tertarik untuk melakukan penelitian tentang pengaruh peresepan obat rasional di RSUD Dr. Pirngadi Kota Medan berdasarkan standar WHO tahun 2012, dengan judul penelitian "Analisis Obat Oleh Dokter dalam Peresepan Penggunaan Obat Rasional Pada Kasus ISPA Non Pneumonia di Rumah Sakit Umum Dr. Pirngadi Kota Medan".

\section{METODE PENELITIAN}

Jenis penelitian yang digunakan dalam penelitian ini adalah survei analitik dengan rancangan cross sectional study. Penelitian ini dilakukan di RSUD Dr. Pirngadi Kota Medan dengan pertimbangan di RSUD ini sudah akreditasi dan penanggung jawab pengelola obat adalah profesi seorang Apoteker. Penelitian ini dilakukan dari bulan Agustus sampai bulan Oktober tahun 2020. Sampel dalam penelitian ini seluruh dokter umum, dokter spesialis paru, dokter spesialis anak dan dokter spesialis penyakit dalam yang membuat resep di RSUD Dr. Pirngadi Kota Medan sebanyak 79 orang dokter. Data pada penilitian ini yaitu data primer, data sekunder dan data tertier. Data penelitian di analisis dengan Chi Square dan regresi linier dengan uji nilai $p=0,05$.

\section{HASIL}

Tabel 1. Distribusi Responden di RSUD Dr.Pirngadi Medan Tahun 2020

\begin{tabular}{|c|c|c|c|c|c|}
\hline Jenis Kelamin & & & & $\%$ & \\
\hline Perempuan & & & & 49,37 & \\
\hline Laki-laki & & & & 50,63 & \\
\hline $\begin{array}{c}\text { Kelompok } \\
\text { Umur }\end{array}$ & $\%$ & Mean & $\begin{array}{c}\text { Standar } \\
\text { Deviation }\end{array}$ & Minimum & Maximum \\
\hline 37 & 8,86 & 42,29 & 0,395 & 27 & 60 \\
\hline Tingkat Pendidikan & & & & $\%$ & \\
\hline Dokter umum & & & & 51,89 & \\
\hline Dokter spesialis anak & & & & 15,19 & \\
\hline Dokter spesialis paru & & & & 6,33 & \\
\hline $\begin{array}{l}\text { Dokter Spesialis Penyakit } \\
\text { dalam }\end{array}$ & & & & 26,6 & \\
\hline Jumlah & & & & 100 & \\
\hline
\end{tabular}


Berdasarkan tabel 1 di atas, diketahui bahwa dari 79 responden, sebagian besar responden berjenis kelamin laki-laki yaitu sebanyak 40 $(50,63 \%)$ responden dan responden berjenis kelamin perempuan ada sebanyak 39 (49,37\%) responden, sebagian besar responden berumur 40 tahun yaitu sebanyak $16(20,25 \%)$ responden, dengan nilia rata-rata umur 42,29, standar devition 0,395, nilai minimum 27 dan nilai maximum 60. Dari 79 responden diketahui bahwa sebagian besar responden berpendidikan dokter umum yaitu sebanyak 41 $(51,89 \%)$ responden.

Tabel 2. Analisis Penggunaan Obat Rasional Dalam Peresepan Pada Kasus ISPA Non Pneumonia di Rumah Sakit Umum Dr. Pirngadi Kota Medan

\begin{tabular}{|c|c|c|c|c|c|c|c|}
\hline & \multicolumn{6}{|c|}{ Penggunaan Obat Rasional } & \multirow{3}{*}{ P value } \\
\hline & \multicolumn{2}{|c|}{ Rasional } & \multicolumn{2}{|c|}{ Tidak Rasional } & \multicolumn{2}{|c|}{ Total } & \\
\hline & $\mathbf{n}$ & $\%$ & $\mathbf{n}$ & $\%$ & $\mathbf{n}$ & $\%$ & \\
\hline \multicolumn{8}{|c|}{ Tepat Diagnosis } \\
\hline Tepat & 38 & 80,85 & 9 & 19,15 & 47 & 100 & \\
\hline Kurang Tepat & 4 & 18,18 & 18 & 81,82 & 22 & 100 & 0,000 \\
\hline Tidak Tepat & 1 & 10,00 & 9 & 90,00 & 10 & 100 & \\
\hline \multicolumn{8}{|l|}{ Tepat Indikasi } \\
\hline Tepat & 34 & 85,00 & 6 & 15,00 & 40 & 100 & 0,000 \\
\hline Kurang Tepat & 8 & 28,57 & 20 & 71,43 & 28 & 100 & \\
\hline Tidak Tepat & 1 & 9,10 & 10 & 90,90 & 11 & 100 & \\
\hline \multicolumn{8}{|c|}{ Tepat Jenis Obat } \\
\hline Tepat & 38 & 100 & 0 & 0 & 38 & 100 & 0,000 \\
\hline Kurang Tepat & 4 & 13,79 & 25 & 86,21 & 29 & 100 & \\
\hline Tidak Tepat & 1 & 8,33 & 11 & 96,67 & 12 & 100 & \\
\hline \multicolumn{8}{|l|}{ Tepat Dosis } \\
\hline Tepat & 38 & 88,37 & 5 & 11,63 & 43 & 100 & 0,000 \\
\hline Kurang Tepat & 4 & 16,00 & 21 & 84,00 & 25 & 100 & \\
\hline Tidak Tepat & 1 & 9,10 & 10 & 90,90 & 11 & 100 & \\
\hline \multicolumn{8}{|c|}{$\begin{array}{l}\text { Tepat Penilaian } \\
\text { Kondisi Pasien }\end{array}$} \\
\hline Tepat & 38 & 84,44 & 7 & 15,56 & 45 & 100 & \\
\hline Kurang Tepat & 4 & 20,00 & 16 & 80,00 & 20 & 100 & 0,000 \\
\hline Tidak Tepat & 1 & 7,14 & 13 & 92,86 & 14 & 100 & \\
\hline \multicolumn{8}{|c|}{ Tepat Informasi } \\
\hline Tepat & 42 & 93,33 & 3 & 6,67 & 45 & 100 & \\
\hline Kurang Tepat & 1 & 4,55 & 21 & 95,45 & 22 & 100 & 0,000 \\
\hline Tidak Tepat & 0 & 0 & 12 & 100 & 12 & 100 & \\
\hline \multicolumn{8}{|l|}{$\begin{array}{l}\text { Tepat Tindak } \\
\text { Lanjut }\end{array}$} \\
\hline Tepat & 40 & 100 & 0 & 0 & 40 & 100 & \\
\hline Kurang Tepat & 2 & 7,69 & 24 & 92,31 & 26 & 100 & 0,000 \\
\hline Tidak Tepat & 1 & 7,69 & 12 & 92,31 & 13 & 100 & \\
\hline Total & 43 & 54,43 & 36 & 45,57 & 79 & 100 & \\
\hline
\end{tabular}

Berdasarkan tabel 2 diketahui bahwa ada hubungan peresepan obat oleh dokter berdasarkan tepat diagnosis $(0,000<0,05)$. Ada hubungan peresepan obat oleh dokter berdasarkan tepat indikasi $(0,000<0,05)$. Ada hubungan peresepan obat oleh dokter berdasarkan tepat jenis obat $(0,000<0,05)$. Ada hubungan peresepan obat oleh dokter berdasarkan tepat dosis $(0,000<0,05)$. Ada hubungan peresepan obat oleh dokter berdasarkan tepat penilaian kondisi pasien $(0,000<0,05)$. Ada hubungan peresepan obat oleh dokter berdasarkan tepat informasi $(0,000$ $<0,05)$. Ada hubungan peresepan obat oleh dokter berdasarkan tepat tindak lanjut dengan penggunaan obat rasional pada kasus ISPA Non Pneumonia di RSUD Dr. Pirngadi Kota Medan $\quad(0,000<0,05)$ 
Tabel 3 Hasil Tahapan Akhir Analisis Regresi Linier

\begin{tabular}{lcccc}
\hline \multicolumn{1}{c}{ Variabel } & B & P vlue & Exp(B)OR & 95\%Cl for Exp(B) \\
\hline Tepat penilaian kondisi & 2,200 & 0,076 & 9,021 & $0,796-77,264$ \\
pasien & 5,376 & 0,005 & 88,099 & $4,969-93,049$ \\
Tepat informasi & 3,441 & 0,009 & 31,220 & $2,321-41,969$ \\
Tepat tindak lanjut & & & & \\
\hline
\end{tabular}

Berdasarkan tabel 3 di atas dapat dilihat bahwa analisis regresi linier menghasilkan 1 (satu) variabel yang paling dominan dengan penggunaan obat rasional pada kasus ISPA Non Pneumonia di RSUD Dr. Pirngadi Kota Medan, yaitu variabel tepat informasi dengan signifikan 0,005 ( $p$ value $<0,05$ ), $O R=88,099$ $(95 \% \mathrm{Cl}=4,9696-93,049)$ artinya Pasien yang menerima obat dengan tepat informasi 88 kali lebih besar berpeluang mendapat obat rasional dibandingkan dengan yang tidak tepat mendapat informasi. Dengan nilai koefisien B yaitu 5,376 bernilai positif, semakin tepat informasi maka semakin rasional pemberian obat.

\section{PEMBAHASAN}

Hasil penelitian yang dilakukan terhadap dokter tentang peresepan obat oleh dokter berdasarkan tepat diagnosis dengan penggunaan obat rasional pada kasus ISPA Non Pneumonia di RSUD Dr. Pirngadi Kota Medan sebanyak 35 (44,30\%) responden setuju bahwa penggunaan obat disebut tepat jika diberikan untuk diagnosis yang tepat. ISPA juga bisa disebabkan oleh infeksi bakteri. ISPA yang disebabkan oleh bakteri biasanya bisa menimbulkan gejala yang lebih berat, sehingga membutuhkan antibiotik untuk mengatasinya. Penularan virus atau bakteri ini bisa melalui kontak langsung dengan pengidapnya, seperti melalui percikan air liur. Virus atau bakteri ini bisa menyebar melalui udara, dan masuk ke hidung atau mulut orang lain. Tidak hanya itu, penyebaran ISPA juga dapat melalui sentuhan dengan benda yang terkontaminasi, bahkan berjabat tangan dengan pengidapnya.

Hasil penelitian juga menunjukkan bahwa sebanyak $33(41,77 \%)$ responden sangat setuju bahwa peresepan obat dilakukan pada pasien yang mengalami gangguan pernapasan, apabila dokter telah memeriksa gejala dan penyakit lain yang pernah dialami. Selanjutnya, dokter akan memeriksa hidung, telinga, dan tenggorokan untuk mendeteksi kemungkinan infeksi. Dokter juga akan memeriksa suara napas dengan stetoskop untuk memantau apakah ada penumpukan cairan atau peradangan pada paru-paru.

Pemeriksaan akan dimulai ketika seseorang mengalami gangguan pernapasan.
Di sini dokter memeriksa gejala dan penyakit lain yang pernah di alami. Selanjutnya, dokter akan melihat kondisi hidung, telinga, dan tenggorokan untuk mendeteksi kemungkinan infeksi. Andaikan seseorang mengalami sesak napas, maka dokter akan melakukan pemeriksaan kadar oksigen dalam tubuh. Andaikan ISPA disebabkan oleh virus, maka dokter tidak akan melakukan pemeriksaan lebih lanjut. Sebab, kondisi ini bisa sembuh dengan sendirinya. Dokter akan mendiagnosis ISPA dengan melakukan wawancara medis, pemeriksaan fisik, dan pemeriksaan penunjang jika diperlukan, seperti: Pemeriksaan darah di laboratorium, Pengambilan sampel dahak untuk diperiksa di laboratorium, Pencitraan dengan x-ray atau CT scan untuk menilai kondisi paru-paru.

Setiap obat memiliki spektrum terapi yang spesifik, misalnya pemberian obat antibiotik diindikasikan untuk pasien yang memberi gejala adanya infeksi bakteri. Berdasarkan hasil jawaban responden diketahui bahwa dari 79 orang responden yang diteliti diketahui bahwa sebanyak 35 (44,30\%) responden setuju bahwa dokter meresepkan obat yang sesuai dengan kebutuhan klinis pasien, dalam dosis yang sesuai dengan kebutuhan individual. Misalnya pasien yang mengalami demam, maka dokter meresepkan obat penurun panas golongan paracetamol.

Peneliti juga menemukan bahwa ada sebanyak $33(41,77 \%)$ responden sangat setuju bahwa dokter akan meresepkan obat penurun panas apabila pasien yang masih bayi mengalami demam $>38,5^{\circ} \mathrm{C}$. Contohnya pada kasus demam berdarah dokter harus memastikan terlebih dahulu demam yang muncul disertai gejala lain seperti ruam kemerahan di kulit yang dicurigai demam berdarah dengue atau DBD sehingga perlu dilakukan pemeriksaan darah. Sehingga dokter tidak meresepkan ibuprofen untuk penurun demamnya.

Selain itu ditemukan juga sebanyak 35 $(44,30 \%)$ responden setuju bahwa dokter akan meresepkan antibiotik kepada pasien apabila ada ditemukan hasil pemeriksaan klinis dan tanda-tanda infeksi pada pasien tersebut. Salah satu tanda-tanda infeksi adalah demam atau tepatnya terjadi reaksi yang menggambarkan adanya proses dalam tubuh, 
suhu tubuh naik akibat tubuh sedang memerangi infeksi sehingga terjadi demam atau menunjukkan adanya proses inflamasi atau peradangan yang menimbulkan demam sehingga dokter cenderung memberikan antibiotik apabila tidak didukung oleh pemeriksaan laboratorium atau pemeriksaan penunjang. Ada juga demam yang hanya disertai dengan gejala batuk dan pilek saja yang menunjukkan adanya ISPA yang tidak spesifik sehingga tidak membutuhkan antibiotik, pasien cukup diberikan obat demam dan flu.

Dari 79 orang pasien yang diteliti diketahui bahwa sebanyak 32 (40,51\%) responden setuju bahwa dokter akan meresepkan antibiotik sesuai dengan jenis bakteri yang menyebabkan infeksi pada saluran pernafasan pasien. Ada dokter meresepkan antibiotik tidak sesuai dengan jenis bakteri penyebab, sehingga bakteri tersebut menjadi resisten terhadap golongan antibiotik tersebut yang menyebabkan infeksi yang lebih parah dikemudian hari, oleh sebab itu dokter diharapkan lebih berhati-hati rasional dalam memilih golongan antibiotik terhadap bakteri penyebab.

Dari 79 orang pasien yang diteliti diketahui bahwa sebanyak 35 (44,30\%) responden sangat setuju bahwa dokter akan meresepkan obat selalu didasarkan symptomatis. Ada juga dokter yang tidak langsung meresepkan obat berdasarkan symptomatis misalnya dengan batuknya, kemungkinan batuk disebabkan oleh alergi sehingga dokter bukan meresepkan obat batuk tapi meresepkan obat alergi seperti golongan kortikosteroid.

Tepat jenis obat adalah penentuan kesesuaian obat yang diresepkan dengan diagnosis yang ditegakkan oleh kemampuan dan pengalaman dokter berdasarkan prinsipprinsip ilmiah. Dari hasil penelitian yang dilakukan di RSUD Dr. Pirngadi Kota Medan dapat dilihat bahwa antibiotik yang digunakan sudah sesuai dengan jenis antibiotik yang ada pada standar Pharmaceutical Care untuk penyakit ISPA. Hasil penelitian menunjukkan bahwa dokter banyak meresepkan golongan obat cefadroxil monohidrat pada ISPA non Pneumonia.

Dari 79 orang dokter yang diteliti diketahui bahwa sebanyak $34 \quad(43,03 \%)$ responden sangat setuju bahwa dokter hanya akan meresepkan Diphenhydramine kepada pasien yang mengalami pilek, Diphenhydramine adalah obat yang digunakan untuk meredakan reaksi alergi pada tubuh, seperti mata merah, iritasi, gatal, dan berair; bersin-bersin, serta pilek. Selain itu, obat ini juga dapat digunakan untuk meredakan batuk yang disebabkan iritasi tenggorokan ringan atau saluran pernapasan, mencegah dan mengobati mabuk perjalanan.

Diphenhydramine terkadang digunakan untuk mengatasi insomnia jangka pendek, namun manfaat dan risikonya masih dipertanyakan. Bahkan konsumsi diphenhydramine rutin untuk mengatasi insomnia dapat menurunkan kualitas tidur, serta menimbulkan rasa kantuk di siang hari. Diphenhydramine merupakan golongan obat antihistamin. Obat ini bekerja dengan cara menghentikan atau memblokir aksi histamin, yaitu zat kimia alami dalam tubuh yang menyebabkan gejala alergi.

Sebanyak $33(43,04 \%)$ responden setuju bahwa dokter hanya akan meresepkan pseudoephedrine kepada pasien yang mengalami hidung tersumbat. Pseudoephedrine adalah obat yang dapat digunakan untuk mengatasi gejala hidung tersumbat pada kasus flu atau pilek, serta penyakit

pernapasan lainnya. Pseudoephedrine bisa ditemukan sebagai kandungan tunggal atau kombinasi dengan obat lain. Pseudoephedrine merupakan obat golongan dekongestan yang bekerja dengan cara meredakan pembengkakan pembuluh darah di dalam hidung, sehingga saluran napas lebih terbuka dan napas menjadi lega.

Sebanyak $32(40,51 \%)$ responden sangat setuju bahwa dokter hanya akan meresepkan antibiotik pada pasien yang ditemukan terpapar bakteri. Karena tidak semua pasien ISPA non Pneumonia disebabkan oleh bakteri, ada juga yang terpapar oleh virus, jamur dan parasit lainnya. Sebanyak 35 (44,30\%) responden sangat setuju bahwa dokter hanya akan meresepkan obat batuk apabila pasien mengalami batuk. Adapun beberapa jenis obat batuk yang dapat meredakan batuk adalah golongan ekspektorat, obat batuk jenis ini akan meningkatkan terjadinya batuk untuk mengeluarkan mukus dari saluran pernafasan, untuk golongan mukoregulator adalah obat batuk yang bisa mengurangi proses hipersekresi dahak kronik melalui penurunan aktifitas anti inflamasi atau menghambat fisiologis dahak tertentu, golongan mukolitik obat batuk yang berpotensi mengurangi kekentalan dahak, golongan mukokinetik adalah obat batuk yang dapat meningkatkan pergerakan mukosilia saluran nafas dan mengencerkan dahak sehingga volumenya bertambah dan lebih mudah dikeluarkan. Ada juga pasien yang mengalami batuk diakibatkan alergi sehingga membutuhkan obat anti alergi.

Seharusnya diberikan dari lini pertama terlebih dahulu untuk mengurangi efek 
samping resistensi. Amoxicilin merupakan antibiotik lini pertama yang diberikan kepada pasien yang membutuhkan terapi antibiotik. Antibiotik yang digunakan berbeda-beda antara satu pasien dengan pasien lainnya, perbedaan ini mungkin disebabkan karena perbedaan pola pemikiran dokter tentang penegakan terapi empiris khususnya penggunaan antibiotik berdasarkan gejala atau kondisi pasien. $^{7}$

Pada penelitian ini jenis antibiotik yang diberikan kepada pasien sesuai dengan standar yang ada pada Pharmaceutical Careseperti amoxicilin, cefadroxil, amoxicilin klavulanat, ciprofloxacin, cotrimoxazol. Pemilihan antibiotik lini ketiga seperti ciprofloxacin harus diperhatikan karena antibiotik ini tidak dianjurkan pada wanita hamil atau menyusui, anak-anak dalam pertumbuhan karena dapat menghambat pertumbuhan tulang, pada penderita gangguan SSP juga perlu diperhatikan pemberiannya. Ketika mengevaluasi kondisi pasien sebelum memulai terapi obat, hal yang penting untuk di pertimbangkan adalah reaksi samping pada individu pasien meliputi terjadinya efek samping, gangguan fungsi hati atau ginjal, dan adanya obat lain yang dapat berinteraksi yang merugikan.

Pasien yang memiliki kondisi khusus seperti gangguan fungsi ginjal, gangguan fungsi hati, alergi obat harus diberikan pengobatan yang sesuai dengan kondisi khususnya. Jika tidak diperhatikan secara khusus, maka akan menyebabkan kerugian yang sangat fatal terhadap si pasien. Indikator penilaian tepat pasien adalah jika pasien tidak mengalami keadaan kontra indikasi terhadap suatu antibiotik yang diberikan. Jika si pasien mengalami kontra indikasi terhadap antibiotik yang diberikan maka akan dinilai sebagai tidak tepat pasien.

Efek samping dari antibiotik biasanya seperti reaksi hipersensitifitas (alergi), akan tetapi tidak semua orang akan mengalami reaksi hipersinsitifitas. Untuk menghindari terjadinya efek samping ini, biasanya bisa dilakukan skin test pada sediaan antibiotik yang berupa parenteral, sedangkan untuk sediaan antibiotik oral biasanya dokter akan menanyakan secara langsung kepada pasien apakah pasien memiliki riwayat alergi terhadap antibiotik atau tidak.

Dosis, cara dan lama pemberian obat sangat berpengaruh terhadap efek terapi obat. Pemberian dosis yang berlebihan, khususnya untuk obat yang dengan rentang terapi yang sempit, akan sangat beresiko timbulnya efek samping. Sebaliknya dosis yang terlalu kecil tidak akan menjamin tercapainya kadar terapi yang diharapkan. Hasil jawaban responden diketahui bahwa sebanyak 32 (40,51\%) responden sangat setuju bahwa Dokter hanya akan meresepkan obat sesuai dengan umur pasien dan sebanyak $34(43,03 \%)$ responden sangat setuju bahwa dokter hanya akan meresepkan obat sesuai dengan berat badan pada anak dan menyatakan bahwa dokter hanya akan meresepkan obat sesuai dengan perhitungan (range), dokter hanya akan meresepkan obat sirup anak kepada pasien anak - anak, dokter hanya akan meresepkan Drop pada bayi.

Tepat regimen meliputi ketepatan dalam memberikan dosis, ketepatan dalam menentukan frekuensi penggunaan obat, juga ketepatan dalam lama pengunaan suatu obat tersebut. Pemberian obat yang harus diberikan kepada pasien untuk menghasilkan efek terapi yang diharapkan tergantung kepada banyak faktor, antara lain usia, bobot badan, kelamin, besarnya permukaan badan, beratnya penyakit, dan keadaan daya tangkis penderita dan faktor ADME (absorpsi, distribusi, metabolisme, dan eksresi. Adanya asumsi dari tenaga kesehatan (dokter, perawat, farmasis) yang lebih menekankan keamanan obat dan meminimalisir efek toksik terkadang sampai mengorbankan sisi efektivitas terapi. ${ }^{8}$

Pasien yang menerima obat dalam jumlah lebih kecil dibandingkan dosis terapinya, frekuensi penggunaan tidak sesuai, dan lama pemberian antibiotik kurang dari standarnya, dapat menjadi masalah yang besar karena menyebabkan tidak efektifnya terapi sehingga pasien tidak sembuh, atau bahkan dapat memperburuk kondisi kesehatannya.

Pada penelitian ini dibahas tentang ketetapan regimen (dosis, frekuensi, lama pemberian), hasil dari data dibandingkan dengan Pharmaceutical Care untuk penyakit ISPA. Untuk penggunaan antibiotik amoxicilin pada pasien dewasa dosis standarnya menurut Pharmaceutical Careberkisar 250-500 $\mathrm{mg}$ dengan frekuensi tiga kali sehari, lama pemberian untuk terapi empiris minimal 5 hari. Penggunaan antibiotik amoxicilin pada data nomor diatas dapat dilihat bahwa dosis amoxicilin yang diberikan $500 \mathrm{mg}$ dengan frekuensi tiga kali sehari dan lama pemberian 5 hari. Dapat di evaluasi bahwa regimen yang diberikan untuk amoxicilin sudah sesuai dengan standarnya.

Untuk ketepatan regimen penggunaan antibiotik cefadroxil menurut standar Pharmaceutical care,dosis pada pasien dewasa sebesar $500 \mathrm{mg}-1$ gram dengan frekuensi penggunaan dua kali sehari, lama pemberian untuk terapi empiris minimal 5 hari. Penggunaan antibiotik cefadroxil diketahui 
bahwa dosis cefadroxil yang diberikan $500 \mathrm{mg}$ dengan frekuensi dua kali sehari dan lama pemberian 5 hari. Dapat di evaluasi bahwa regimen yang diberikan untuk cefadroxil sudah sesuai dengan standarnya.

Untuk ketepatan regimen penggunaan antibiotik amoxiclavulanat menurut standar Pharmaceutical care, dosis pada pasien dewasa sebesar $625 \mathrm{mg}$ dengan frekuensi penggunaan tiga kali sehari, lama pemberian untuk terapi empiris minimal 5 hari. Penggunaan antibiotik amoxiclavulanat pada nomor diatas dapat dilihat bahwa dosis amoxiclavulanat yang diberikan $625 \mathrm{mg}$ dengan frekuensi tiga kali sehari dan lama pemberian 5 hari. Evaluasi regimen yang diberikan untuk amoxiclav sesuai dengan standarnya.

Untuk ketepatan regimen penggunaan antibiotik ciprofloxacin menurut standar Pharmaceutical care, dosis pada pasien dewasa sebesar 500-750 $\mathrm{mg}$ dengan frekuensi penggunaan dua kali sehari, lama pemberian untuk terapi empiris minimal 5 hari. Penggunaan antibiotik ciprofloxacin pada nomor diatas dapat dilihat bahwa dosis ciprofloxacin yang diberikan $500 \mathrm{mg}$ dengan frekuensi dua kali sehari dan lama pemberian 5 hari. Dapat di evaluasi bahwa regimen yang diberikan untuk ciprofloxacin sudah sesuai dengan standarnya Untuk ketepatan regimen penggunaan antibiotik cotrimoxazol menurut standar Pharmaceutical care, dosis pada pasien dewasa sebesar 480-960 mg dengan frekuensi penggunaan dua kali sehari, lama pemberian untuk terapi empiris minimal 5 hari. Penggunaan antibiotik cotrimoxazol pada nomor diatas dapat dilihat bahwa dosis cotrimoxazol yang diberikan $2 \times 480 \mathrm{mg}$ dengan frekuensi dua kali sehari dan lama pemberian 5 hari. Dapat di evaluasi bahwa regimen yang diberikan untuk cotrimoxazol sudah sesuai dengan standarnya.

Respon individu terhadap efek obat sangat beragam terlihat pada beberapa jenis obat misalnya pemberian obat B-bloker (propanolol) hendaknya tidak diberikan pada penderita hipertensi yang memiliki riwayat asma, karena obat ini memberikan efek bronkhospasme. Antiinflamasi Non Steroid (AINS) sebaiknya juga dihindari pada penderita asma, karena obat golongan ini terbukti dapat mencetuskan serangan asma. Peresepan kuinolon (misalnya siprofloksasin dan ofloksasin), tetrasiklin, metronidazol pada ibu hamil sama sekali harus dihindari,mkaren memberikan efek buruk pada janin yang di kandung.

Hal lebih jelas terlihat pada beberapa jenis obat seperti teofilin dan aminoglikosida. Pada penderita dengan kelainan ginjal, pemberian aminoglikosida sebaiknya dihindarkan, karena resiko terjadinya nefrotoksisitas pada kelompok ini meningkat secara bermakna.

Informasi yang tepat dan benar dalam penggunaan obat sangat penting dalam menunjang keberhasilan terapi. Peresepan rifampisin akan mengakibatkan urin penderita berwarna merah. Jika hal ini tidak diinformasikan, penderita kemungkinan besar akan menghentikan minum obat karena menduga obat tersebut menyebabkan kencing disertai darah. Padahal untuk penderita tuberkulosis, terapi dengan rifampisin harus diberikan dalam jangka panjang.

Peresepan antibiotik harus disertai informasi bahwa obat tersebut harus diminum sampai habis selama satu kurun waktu pengobatan (1 course of treatment), meskipun gejala-gejala klinik sudah mereda atau hilang sama sekali. Interval waktu minum obat juga harus tepat, bila 4 kali sehari berarti tiap 6 jam. Untuk antibiotik hal ini sangat penting, agar kadar obat dalam darah berada di atas kadar minimal yang dapat membunuh bakteri penyebab penyakit.

Peneliti berasumsi bahwa waspada efek samping adalah suatu tindakan yang dilakukan tenaga kesehatan oleh dokter maupun tenaga farmasi dalam mewaspadai efek samping obat yang mungkin terjadi terhadap pasien. Waspada efek samping dapat dilakukan dengan memberikan informasi-informasi yang tepat kepada pasien, memberika pendidikan terkait penyakit yang di deritanya, seperti meminum antibiotik harus sampai habis agar tidak terjadi efek yang dapat merugikan pasien seperti resistensi. Pada penggunaan antibiotik, efek samping yang paling sering terjadi seperti reaksi hipersensitivitas dan resistensi.

Pada saat memutuskan pemberian terapi, harus sudah dipertimbangkan upaya tindak lanjut yang diperlukan, misalnya jika pasien tidak sembuh atau mengalami efek samping. Pada terapi dengan teofilin sering memberikan gejala takikardi. Jika hal ini terjadi, maka dosis obat perlu ditinjau ulang atau bisa saja obatnya diganti. Pada penatalaksanaan syok anafilaksis, pemberian injeksi adrenalin yang kedua perlu segera dilakukan, jika pada pemberian pertama respons sirkulasi kardiovaskuler belum seperti yang diharapkan.

Menurut asumsi peneliti, Pada saat memutuskan pemberian terapi, harus sudah dipertimbangkan upaya tindak lanjut yang diperlukan karena akibat yang paling dikhawatirkan dari peresepan antibiotik yang berlebihan adalah terjadinya resistensi terhadap antibiotik. Resistensi antibiotik dapat mengakibatkan dampak yang merugikan baik 
dari segi ekonomi (bertambahnya biaya pengobatan) maupun klinis (bertambahnya keparahan penyakit). Oleh sebab itu, persentase peresepan antibiotik untuk ISPA nonpneumonia diharapkan menjadi serendah mungkin untuk menghindari akibat yang tidak diinginkan.

\section{KESIMPULAN DAN SARAN}

Berdasarkan hasil interpretasi data Obat Oleh Dokter Dalam Peresepan Penggunaan Obat Rasional Pada Kasus ISPA Non Pneumonia Di Rumah Sakit Umum Dr. Pirngadi Kota Medan Ada hubungan peresepan obat oleh dokter berdasarkan tepat diagnosis, berdasarkan tepat indikasi, berdasarkan tepat jenis obat, berdasarkan tepat dosis, berdasarkan tepat penilaian kondisi pasien, berdasarkan tepat informasi , berdasarkan tepat tindak lanjut dengan penggunaan obat rasional pada kasus ISPA Non Pneumonia di RSUD Dr. Pirngadi Kota Medan. Variabel yang dominan berhubungan dengan peresepan obat oleh dokter dengan penggunaan obat rasional pada kasus ISPA Non Pneumonia di RSUD Dr. Pirngadi Kota Medan adalah variabel tepat informasi.

\section{Saran}

Bagi Rumah sakit

a. Hasil penelitian ini dapat menjadi sumber data dasar untuk meningkatkan penggunaan obat yang rasional di rumah sakit sehingga diharapkan memberikan dampak terhadap pengembangan keilmuan dalam pemecahan masalah peresepan obat yang tidak rasional di rumah sakit dan masyarakat. Kedisiplinan dalam menuliskan diagnosis pasien dalam resep dengan memperhatikan kebenaran kode yang digunakan, melakukan pengukuran berat badan untuk mengetahui dosis yang diperlukan secara lebih akurat.

b. Perlu dilakukan pengecekan ulang pada setiap proses skrining resep dan penyerahan obat terkait dengan kriteria ketepatan rasionalitas yang tercantum dalam modul POR Nasional.

\section{Bagi Dokter}

Sebaiknya dalam penyerahan obat dokter harus mengkomunikasikan kepada pasien cara yang tepat untuk menggunakan obat melalui informasi mengenai :

a. Etiket obat yang mencantumkan informasi mengenai nama pasien, nama obat, petunjuk penggunaan obat, tanggal pemberian obat, identitas pemberi resep. Instruksi berupa simbol, untuk pasien yang buta huruf.

b. Pemberian label/etiket informasi tambahan untuk obat.

c. Mengulang secara lisan, instruksi yang tertulis pada etiket, jika memungkinkan dalam bahasa yang jelas dan lugas, yang dimengerti oleh pasien.

d. Meminta pasien untuk mengulang instruksi yang diberikan.

e. Menginformasikan peringatan dan perhatian terkait penggunaan obat.

f. Memberikan perhatian khusus terhadap kondisi tertentu seperti wanita hamil, pasien yang memiliki gangguan penglihatan dan pendengaran, buta huruf, anak dan pasien lansia dan pasien yang mendapatkan lebih dari satu jenis obat.

\section{DAFTAR PUSTAKA}

1. Munjal, YP S. API textbook of medicine; 2002.

2. DEPKES, Republik Indonesia. Sistem kesehatan nasional. 2009.

3. Keputusan Menteri Kesehatan Republik Indonesia Nomor 189/ Menkes/SK/III/2012 tentang Kebijakan Obat Nasional (Konas)

4. World Health Organization. The World Medicine Situation 2019 3ed. Rational Use of Medicine. Geneva; 2019.

5. Kemenkes RI. Pedoman Pelayanan Kefarmasian untuk Terapi Antibiotik, Kementrian Kesehatan Republik Indonesia, Jakarta; 2011b

6. Penggunaan Obat Rasional.jakarta:Departemen Kesehatan RI.2017.

7. Anonim. A Prescription for Better Prescribing, British Journal of Clinical Pharmacology, 487-491.: 2006

8. Cipolle, Robert J.; Strand, Linda M.; Morley, Peter C. Pharmaceutical care practice. McGraw-Hill, 1998 